Three new records of Anthocerotophyta for Western Africa (Sierra Leone) based on spore ornamentation of A. Harrington specimen, with an emphasis on Anthoceros sect. Fusiformes Grolle

Cecília Sérgio ${ }^{\mathrm{a}}$, David Draper ${ }^{\mathrm{a}, \mathrm{b}}$, Ronald D. Porley ${ }^{\mathrm{c}}$

${ }^{a}$ Museu Nacional de História Natural e da Ciência/ CE3C-Centre for Ecology, Evolution and Environmental Changes. Rua da Escola Politécnica, 58, 1250-102 Lisboa, Portugal. E-mail: csergio@,fc.ul.pt*

bUBC Botanical Garden \& Centre for Plant Research, and Department of Botany, University of British Columbia, Vancouver, Canada.

${ }^{\mathrm{c}}$ Cerca dos Pomares, CxP 409M, Aljezur, Portugal.

*Author contact information

“This is an Author's Original Manuscript of an article published by Taylor \& Francis in Journal of Bryology, 2020 available online at the Taylor \& Francis Ltd website: https://doi.org/10.1080/03736687.2019.1709022 


\title{
Three new records of Anthocerotophyta for Western Africa (Sierra Leone) based on spore ornamentation of A. Harrington specimen, with an emphasis on Anthoceros sect. Fusiformes Grolle
}

\begin{abstract}
During an investigation into the world-wide distribution of Anthoceros caucasicus Steph., we examined a Sierra Leone voucher collected by A.J. Harrington in 1966 and subsequently studied by E.W. Jones. Based on spore observations using light and scanning electron microscopy we found that three Anthocerotophyta taxa were present in this mixed collection. We report Anthoceros aff. bharadwajii Udar \& A.K. Asthana new to Africa, Phaeoceros laevis (L.) Prosk. new to Sierra Leone and Tropical Africa, and Anthoceros punctatus L. new to Sierra Leone and western mainland Africa. We conclude that $A$. caucasicus should be removed from the Sierra Leone bryoflora, and possibly from Tropical Africa.
\end{abstract}

The bryophyte flora of Sierra Leone has for many decades been neglected. In the past 35 years knowledge of the bryophyte flora of this small West African country has increased very little, and there have been no new hepatic records until now. Wigginton (2018) cited 140 liverworts and 2 hornworts for Sierra Leone and O'Shea (2006) 
mentioned 102 moss species, but there is no up-to-date checklist. Many species, even common ones, have been documented only from one or just a few localities.

During an investigation into the world-wide distribution of Anthoceros caucasicus Steph. (syn. A. mandonii Steph.), we studied a Sierra Leone specimen (Jones \& Harrington, 1983) deposited in BM labelled as A. mandonii (Figure 1). The material was collected in the region of Bintimani, the highest peak of the Loma Mountains in the northeast part of the country, at an altitude of 1830 to 1940 m (Jones \& Harrington 1983).

\section{Figure 1.}

In 1980 E.W. Jones examined the material, and inside the voucher is his handwritten note (Figure 2) with important observations concerning the gathering. He indicates, with reservations, that the material comprises possible Anthoceros mandonii, one other hornwort and a Fossombronia.

\section{Figure 2.}

"Two species of Anthoceros here, intimately mixed. I have been able to find only detached old sporangia, \& do not know which species they came from, nor have I been able to recover any spores in good enough condition to be certain of the 'ornamentation' of the wall.

(a) Thalli prostrate, irregularly branched, more or less parallel sided though often with margins slightly undulate, $1-1.5 \mathrm{~mm}$ wide. Antheridia $4-5$ per chamber, globose, $200-250 \mu \mathrm{m}$ long. No 9 found.

(b) Caespitose, branches ca. $5 \mathrm{~mm}$ tall ascending from stoloniferous basal shoots with dense rhizoids, the ascending shoots convolute, rapidly expanded upwards into a laciniate trumpet-like lamina with numerous short laciniae on the upper surface. 
(c) Fossombronia with colourless rhizoids,

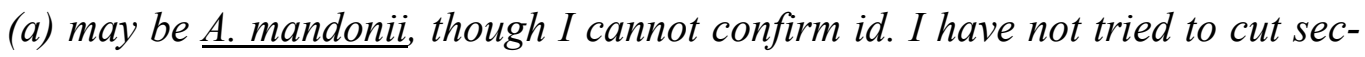
tions of the thallus, but I am not convinced that it isn't Phaeoceros. The antheridium seems to be Phaeoceros!

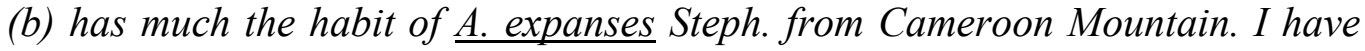
seen spores in the type, but spores of EWJ 445 from Cameroon Mt, which I take to be the same species, are of the 'Mandonii' type but only $28-30 \mu \mathrm{m}$ diam.

E W Jones 30 March 1980”

The condition of the gametophytes inside the packet is impoverished and corresponds to a mixture of thalli. As Jones noted, it is difficult if not impossible to associate the few sporophytes present with the fragments of thalli to which they were originally attached. The voucher actually comprises three mini-packets: two with mixed thalli and one with two or three isolated and incomplete sporophytes. Jones was of the opinion that the collection comprised two Anthocerotae and one Fossombronia. Concerning both points (a) above and (a) below in his annotations (Figure 2) he expressed his doubt about the identity of Anthoceros mandonii Steph., suggesting it may be Phaeoceros based on the morphology of the antheridia.

The occurrence of antheridia was observed in a few thalli but the material is too impoverished to observe gametophytic structures. However, besides some small plants of Fossombronia husnotii Corb. and Bryum sp., the remaining thalli and sporangium fragments were identified as hornworts. Soil admixed with the thalli was carefully examined for the presence of spores and some spores were also carefully removed from sporangia avoiding as far as possible damage to the capsule walls. Spores were photographed under a trinocular light microscope (LM), followed by scanning electron 
microscopy (JEOL-SM 5200 LV) at the Faculty of Sciences, University of Lisbon, to reveal the microstructure of spore wall.

Hornworts have a rather uniform gametophyte and sporophyte morphology (Hässel de Menéndez 1989; Zhang \& Wu 2006; Renzaglia et al. 2009), in contrast to the spore wall ornamentation which have long been used in taxonomic studies of not only hornworts but other plant groups and in palaeobotanical studies (Taylor et al. 2009). The colour, size and sculpture of spores are important characters and the distinctive ornamentation including the tri-radiate mark provides a critical and often sole means for the identification of Anthocerotopsida.

Anthoceros s.str. is characterized by grey to blackish coloured spores but the features and texture of the sporoderm, including processes (papillae, spines, mamillae or bacula), proximal pits and reticulum also provide important information. In addition, the presence of strips along the laesura (tri-radiate mark) is used in the diagnoses of Anthoceros section Fusiformes.

In this mixed gathering, notwithstanding that it was only possible to examine sporophytes and spores, we were able to establish that three species of Anthocerotophyta are present. Employing both LM (Figure 3) and SEM (Figures 4, 5) to elucidate spore ornamentation, we have established the presence of both Anthoceros punctatus L. (see below) and Phaeoceros laevis (L.) Prosk. s. lat. (Figure 5).

Furthermore, other Anthoceros spores recovered from the fragmentary material do not correspond to the aforementioned species or indeed to Anthoceros caucasicus, but to a taxon within the "Anthoceros fusiformes group" (Proskauer, 1951; 1958), now placed in section Fusiformes Grolle (Grolle 1976). Even though the spores are rather old and not in perfect condition, it is our opinion that they belong to, or are very closely related to, Anthoceros bharadwajii Udar \& A.K. Asthana. A. caucasicus and A. bharadwajii are in 
the same group, a section currently inadequately circumscribed but with high phytogeographic importance (Sérgio 1987; 1990; Hasegawa 1993).

As there are limited data on Anthocerotophyta in Africa, together with little current collecting effort on the continent, the conclusions gained from this historical sample are, we believe, an important contribution to knowledge of this group in Africa. It is also widely acknowledged that the presence of Anthocerotophyta taxa is important to a better understanding of the taxonomic evolution of this group and to the environmental conditions that existed in the past.

\section{Anthoceros aff. bharadwajii Udar \& A.K. Asthana}

Anthoceros bharadwajii was originally reported for South India (Udar \& Asthana 1985a; Asthana \& Srivastava 1991b), and later from the Himalayas and North and South India (Singh \& Singh 2008; Gupta \& Asthana 2015). It was also reported for China from Yunnan province (Peng \& Zhu 2013).

Udar and Asthana (1985a) reported variation in Anthoceros bharadwajii spores from different samples, but the anatomy is very typical, as evidenced by SEM images (Zhang 2006; Singh and Singh 2008; Peng and Zhu 2013). The spore wall ornamentation was compared with two samples of $A$. bharadwajii from HSNU and PSU and they clearly matched.

The Sierra Leone spores (Figures 3a-c, 4a-c) are dark brown, 40-58 $\mu \mathrm{m}$ in diameter, the distal face with baculate projections (2-3 $\mu \mathrm{m}$ high), united at the base forming a more or less lamellate-reticulate pattern with ridged areas, densely studded with stout projections having a blunt-dentate apex and the proximal face with a distinct tri-radiate mark bordered by two smooth or unsculptured stripes along the laesura (in total $c a$. 8-12 
$\mu \mathrm{m}$ wide), terminating shortly before margin so not reaching the equator. Spore size reported by Udar \& Asthava (1985b) and Peng \& Zhu (2013) is given as 35-55 $\mu \mathrm{m}$, compared to the spores observed from Sierra Leone plants which are (40)43-52(58) $\mu \mathrm{m}$ (Figures 3a-c, 4a-c).

Spore ornamentation of $A$. caucasicus from a Turkish collection (the original provenance) and spores from Iberian Peninsula and Macaronesian material were studied along with the description in Sérgio (1987) and Casas et al. (2009). The spore struture of A. caucasicus are more or less translucent, smoky-grey, not dark (Figures 3g-3i), 42$48 \mu \mathrm{m}$ in diameter, distal sporoderm pattern (Figures $4 \mathrm{~g}$, 4i) with spinose to spinulose papillae, frequently pediculate to $3-5 \mu \mathrm{m}$ high, united at base as lamellae and somewhat reticulate by ridges enclosing both lumina and pits; proximal surfaces roughened with scattered spinose outgrowths, with distinct narrow smooth bands (ca. 6-12 $\mu \mathrm{m}$ wide) along tri-radiate marks that clearly reach the spore margin.

We therefore conclude that A. caucasicus should be removed from the Sierra Leone bryoflora, and possibly from Africa.

It was not possible to draw conclusions based on gametophyte characteristics as the mixed gathering from Sierra Leone is poorly conserved and the few capsules present are separated from the gametophytes.

In the present study we were able to examine material of Anthoceros bharadwajii from China, Yunnan and Thailand enabling comparison with the Sierra Leone collection. The spores of $A$. aff. bharadwajii from Sierra Leone are distinctly opaque (Figures. 3d, 3f), dark brown (not smoky-grey), 41-57 $\mu \mathrm{m}$ in diameter, the distal surface (Figure 4e) with well isolated baculate projections (2-3 $\mu \mathrm{m}$ high), blunt or truncate, some united at base forming more or less lamellate pattern with ridged areas, with proximal faces (Figure 4d) presenting a distinct tri-radiate mark bordered by two smooth or unsculptured 
stripes along the laesura ( $c a .8-12 \mu \mathrm{m}$ wide), ending sharply before the margin, not extending to the equator. Whilst the spores of the Asian collections figured in Singh \& Singh (2008) and Peng \& Zhu (2013) are fully comparable to the Sierra Leone spores, they are nevertheless variable and it cannot be ruled out that the Sierra Leone plant may be closely related, but not identical to, A. bharadwajii.

Anthoceros alpinus Steph., another Asian species belonging to the Fusiformes group (Peng and Zhu 2013), has spores of similar dimensions and colour, but the distal and proximal spore faces show a reticulate pattern with blunt round projections, contrasted with $A$. bharadwajii where the proximal faces of the spores have dense tuberculatebaculate projections, with some lamellae but not reticulate (as in Figures 4a-4c).

Further studies are needed to better understand the Sierra Leone plants in the context of the morphological and genetic variability of $A$. bharadwajii, as well as within the genus Anthoceros overall (Villarreal et al. 2015). Taxonomic studies and phylogenetic approaches are hindered by inadequate sampling on the African continent. However, considering the ecology and the species associated with $A$. aff. bharadwajii, it may be expected in wet mountainous areas in other parts of equatorial and sub-equatorial Africa.

\section{Figure 3.}

Concerning the description and illustrations of spores Spore ornamentation of $A$. caucasicus from the Democratic Republic of Congo in E.W. Jones's Flora of West Africa (Wigginton 2004), based originally on material reported by Vanden Berghen (1972) from the region of La Kafubu (figure 85), as well as figure 440 in the Rwandan publication by Fischer (Fischer 2013; Fischer and Thiel 2015) and the locality reported by Malaisse et al. (2016) in Katanga Haut-Congo, it is certain that they do not correspond to A. caucasicus but belong instead to Anthoceros section Fusiformes. It 
should also be noted that in Jones' notes (Figure 2) he is noncommittal about whether the Sierra Leonean collection contains A. caucasicus (as A. mandonii), and furthermore Vanden Berghen (1972) in the first reference of this species for Africa remarks "c'est avec une certaine hésitation que nous identifions provispirement la plante du Shaba á Anthoceros mandoni".

Specimens examined: SIERRA LEONE. Loma Mountains, Bintimani, on soil bank 12 June 1966., leg. A.J. Harrington 212 (BM001244143 p.p.). CHINA. Yunnan, Gongshan Co., Bingzhongluo village, on soil by road, $1846 \mathrm{~m}$ a.s.1., 20 September 2010, leg. Ying Yu 20100920-7, det. Tao Peng (HSNU). THAILAND. Chiang Mai province, Summit of

Doi Inthanon Mt., Doi Inthanon National Park, 11 November 2011, leg. Chantanaorrapint \& Promma 299 (PSU).

\section{Figure 4.}

\section{Anthoceros punctatus $\mathrm{L}$.}

This widespread hornwort with a worldwide range includes the Mediterranean-Atlantic part of Europe (Hodgetts 2015) from north Denmark to Macaronesia, most Mediterranean Islands, Turkey and the Caucasus (Paton 1999). It also occurs in North and Central America (Stotler \& Crandall-Stotler 2005), in South America from Argentina, Chile, Colombia and Brazil (Hässel de Menéndez \& Rubies 2009; Gradstein \& Pinheiro da Costa 2003), and recently reported in Bolivia (Cykowska \& Mogro in Ellis et al. 2014). It is also reported from Asia (Piippo 1990; Konstantinova et al. 1992; Furuki \& Mizutani 2004) and in Australia (McCarthy 2003). In African countries south of the Sahara it seems to be much less reported, being indicated for Bioko, Cape Verde Islands, Rwanda, Madagascar, Socotra and the Democratic Republic of the Congo (Wiggington 2018). It was also recently reported for Tanzania (Pócs \& Váňa 2015) in East Africa. Although the very similar Anthoceros agrestis can only be separated from 
A. punctatus on antheridial dimensions, it is not known from Africa (Wigginton 2018) and therefore we believe the prudent course of action is to conclude the present material corresponds to A. punctatus and is thus reported here as new to western mainland Africa (Figs. 5a, 5b).

Specimens examined: SIERRA LEONE. Loma Mountains, Bintimani, on soil bank, 12 June 1966, leg. A.J. Harrington 212 (BM001244143 p.p.).

\section{Figure 5.}

\section{Phaeoceros laevis (L.) Prosk.}

This Mediterranean-Atlantic hornwort is considered a cosmopolitan well-defined species (Hasegawa 1984a; Hasegawa 1984b), widespread in the Mediterranean areas of Europe including Macaronesia (Hodgetts 2015). In Africa it is not known from the tropics south of the Sahara (Wiggington 2018). The nearest regions where the species is reported are in Macaronesia (Canary and Madeira Islands) and in North Africa (Morocco, Algeria and Tunisia) (Ros et al. 2007). We therefore report Phaeoceros laevis (L.) Prosk. new to Sierra Leone and new to Tropical Africa.

In the Harrington sample, there are some thalli with male cavities (also observed by E.W. Jones) but since the material is fragmented it is impossible to determine the connectedness or indeed presence of female structures. It is however most likely a dioecious plant and furthermore spores extracted from the sample correspond very well to $P$. laevis and not to $P$. carolinianus.

The closely related Phaeoceros carolinianus (Michx.) Prosk. is reported for Sierra Leone, in a single location, south of Musaia town (Jones \& Harrington 1983). However, spores from Bintimania, leg. A.J. Harrington 212, agree well in the essential characters with spores from European P. laevis s. str. in which the proximal surfaces (Figures $5 \mathrm{c}$, 5d) are densely papillate throughout, and do not present scattered minute papillae only 
in the central part which is typical of $P$. carolinianus (Hässel de Menéndez 1989).

Specimens examined: SIERRA LEONE. Loma Mountains, Bintimani, on soil bank 12 June 1966, leg. A.J. Harrington 212 (BM001244143 p.p.).

\section{Other specimens studied}

Anthoceros caucasicus Steph.

TURKEY. Rize, Çayeli to Kaptanpasa near Yesiltepe, $40^{\circ} 58^{\prime} 01^{\prime \prime} \mathrm{N} 40^{\circ} 47^{\prime} 44^{\prime \prime}$ E, 430 m a.s.1., on soil bank, mountain forest, 23 June 2011, leg. M. Kirmaci \& H. Kürschner (AYDN 2977).

\section{ORCID}

\section{Cecília Sérgio https://orcid.org/0000-0001-5145-5329}

David Draper https://orcid.org/0000-0001-7807-3574

\section{References}

Asthana AK, Srivastava SC. 1991. Indian hornworts (A taxonomic study). Bryophytorum Bibliotheca 42: 1-158.

Casas C, Brugués M, Cros RM, Sérgio C, Infante M. 2009. Handbook of liverworts and hornworts of the Iberian Peninsula and the Balearic Islands Institut d'Estudis Catalans, Barcelona, 177 pp.

Ellis LT, Bayliss J, Bruggeman-Nannenga MA, Cykowska B, Ochyra R, Gremmen NJM, Frahm J-P, Hedderson TA, Heras P, Infante MV, Hugonnot V, Mogro F, Plášek V, Cíhal L, Sawicki J, Schäfer-Verwimp A, Stebel A, Stefanut S, Váňa J, Yang, J-D, Lin S-H. 2014. New national and regional bryophyte records, 38. Journal of Bryology 36: 61-72. 
Fischer E. 2013.The Liverworts and Hornworts of Rwanda $A B C$ taxa 14: 1-570.

Fischer E, Thiel C. 2015. New and noteworthy records of liverworts (Marchantiopsida) and hornworts (Anthocerotopsida) for Rwanda. Nova Hedwigia 100: 525-534.

Furuki T, Mizutani M. 2004. Checklist of Japanese Hepaticaeand Anthoceratae Bryological Research. 8: 296-316.

Gradstein SR, Pinheiro da Costa D. 2003. The Hepaticae and Anthocerotae of Brazil. Memoirs of the New York Botanical Garden 87: 1-318.

Grolle R. 1976. Verzeichnis der Lebermoose Europas und benachbarter Gebiete. Feddes Repertorium 87: 171-279.

Gupta R, Asthana AK. 2015. Hornwort diversity at Pachmarhi Biosphere Reserve (Madhya Pradesh), India. Pl. Sci. Today 2: 145-150.

Hasegawa J. 1984a. Distribution of Japanese species of Anthocerotae. Journal of the Hattori Botanical Laboratory 56: 21-28.

Hasegawa J. 1984b. Taxonomic studies on Asien Anthocerotae IV. A revision of the genera Anthoceros, Phaeoceros and Folioceros in Japan. Journal of the Hattori Botanical Laboratory 57: 241-272.

Hasegawa J. 1993. Taxonomical studies on Asian Anthocerotae V. A short revision of Taiwanese Anthocerotae. Acta Phytotax. Geobot. 44: 94-112.

Hässel de Menéndez G, Rubies FM. 2009. Catalogue of Marchantiophyta and Anthocerotophyta of southern South America [Chile, Argentina and Uruguay, including Easter Is, (Pascua I), Malvinas Is (Falkland Is), South Georgia Is, and the sub-Antarctic South Shetland Is, South Sandwich Is, and South Orkney Is]. Nova Hedwigia Beiheft 134: 1-672. 
Hässel de Menéndez G. 1989 Las especies de Phaeoceros (Anthocerotophyta) de América del Norte, Sud y Central; la ornamentación de sus esporas y taxonomía. Candollea 44: 715-39.

Hodgetts NG. 2015. Checklist and country status of European bryophytes - towards a new Red List for Europe. Irish Wildlife Manuals, $\mathrm{N}^{\circ}$ 84. National Parks and Wildlife Service, Department of the Arts, Heritage and the Gaeltacht, Ireland.

Jones EW, Harrington AJ. 1983. The Hepaticae of Sierra Leone and Ghana. Bulletin of the British Museum (Natural History) Botanical series 11: 215-289.

Konstantinova NA, Potemkin AD, Schljakov RN. 1992. Check-list of the Hepaticae and Anthocerotae of the former USSR. Arctoa 1: 87-127.

McCarthy PM. 2003. Catalogue of Australian liverworts and hornworts. Fl. Australia Suppl. Ser. 21: vi +137 pp.

Malaisse F, Schaijes M, D'Outreligne C. Eds. 2016. Copper-cobalt flora of Upper Katanga and Copperbelt Field Guide Publisher: Les Presses Agronomiques de Gembloux.

O'Shea BJ. 2006. Checklist of the mosses of sub-Saharan Africa (version 5, 12/06).

Paton JA. 1999. The liverwort flora of the British Isles. Colchester: Harley Books, pp. $587-90$

Peng T, Zhu R-L. 2013. A revision of the genus Anthoceros (Anthocerotaceae, Anthocerotophyta) in China. Phytotaxa 100: 21-35.

Piippo S. 1990. Annotated catalogue of Chinese Hepaticae and Anthocerotae. Journal Hattori Botanical Laboratory 68: 1-192.

Pócs T, Váňa J. 2015. East African bryophytes XXX New liverwort records. Acta biologica plantarum Agriensis 3: 3-21. 
Proskauer J. 1951. Studies on Anthocerotales III. 4. The genera Anthoceros and Phaeoceros. Bulletin of the Torrey Botanical Club 78: 331-349.

Proskauer J. 1958. Nachtrag zur Familie Anthocerotaceae, in K Müller, Die Lebermoose Europas, Rabenhorst's Kryptogamen-Flora, 3rd ed, 6: 1303-1319.

Renzaglia KS, Villarreal JC, Duff RJ. 2009. New insights into morphology, anatomy, and systematics of hornworts. In: Goffinet B, Shaw AJ (Eds). Bryophyte Biology $2^{\text {nd }}$ ed Cambridge University Press UK 565 pp.

Ros RM, Mazimpaka V, Abou-Salama U, Aleffi M, Blockeel TL, Brugués M, Cano MJ, Cros RM, Dia MG, Dirkse GM, El Saadawi W, Erdag A, Ganeva A, González- Mancebo JM, Herrnstadt I, Khalil K, Kürschner H, Lanfranco E, Losada-Lima A, Refai MS, Rodrıguez-Nuñez S, Sabovljevic M, Sérgio C, Shabbara H, Sim-Sim M, Söderström L. 2007. Hepatics and Anthocerotes of the Mediterranean, an annotated checklist Cryptogamie, Bryologie 28: 351-437.

Sérgio C. 1987. Contribuição para o estudo taxonómico e fitogeográfico de Anthoceros caucasicus Steph. na Península Ibérica e Macaronesia. Actas del VI Simposio Nacional de Botánica Criptogámica, Universidad de Granada, pp. 605-614.

Sérgio C. 1990. Perspectiva biogeográfica de la flora briológica ibérica. Anales Jardín Botánico de Madrid 46: 371-392.

Singh DK, Singh SK. 2008. Scanning electron microscopic studies on sporoderm of some Indian liverworts and hornworts In: Mohamed H, Baki BB, Nasrulhaq-Boyce A, Lee PKY (eds). Bryology in the New Millennium University of Malaya, Kuala Lumpur. Pp. 291-317.

https://www.researchgate.net/publication/260202668_Scanning_Electron_Microsco pic_Studies_on_Sporoderm_of_Some_Indian_Liverworts_and_Hornworts [accessed Aug 07 2019]. 
Stotler RE, Crandall-Stotler B. 2005. A revised classification of the Anthocerotophyta and a checklist of the hornworts of North America, North of Mexico. Bryologist 108: 16-26.

Taylor TN, Taylor EL, Krings M. 2009. Paleobotany: the biology and evolution of fossil plants. Elselver pp. 1230.

Vanden Berghen C. 1972. Hépatiques et Anthocérotées, in J-J Symoens, (ed), Résultats scientifiques Exploration hydrobiologique du bassin du lac Bangweolo et $d u$ Luapula, 8: 1-220. Bruxelles: Cercle Hydrobiologique de Bruxelles.

Villarreal JC, Cusimano N, Renner SS. 2015. Biogeography and diversification rates in hornworts - the limitations of diversification modelling. Taxon 64: 229-238.

Udar R, Asthana AK. 1985a. Anthoceros bharadwajii a new species from India, Proceedings of the Indian National Science Academy, Biological Sciences 51: 483-488.

Udar R, Asthana AK. 1985b. A new Anthoceros from Nagaland. Journal of the Indian Botanical Society 64: 303-305.

Wigginton MJ (ed). 2004. EW Jones's Liverwort and Hornwort Flora of West Africa Scripta Botanica Belgica 30: I-VII, 1-443.

Wigginton MJ. 2018. Checklist and distribution of the liverworts and hornworts of subSaharan Africa, including the East African Islands. Tropical Bryology Research Reports 9: 1-138.

Zhang Y-L, Wu P-C (eds). 2006 Spore Morphology of Chinese Bryophytes. Qingdao Publishing House, Qingdao pp. 339. 


\section{Legends}

Figure 1. Label of the original sample in BM (BM001244143) corresponding to the specimen collected by A.J. Harrington in 16 June 1966 (Jones \& Harrington 1983). In upper right is faintly indicated $3 \mathrm{spp}$.

Figure 2. A transcript of the note included with the voucher BM (BM001244143) corresponding to the specimen collected by A.J. Harrington, inscribed by E. W. Jones, March 30, 1980.

Figure 3. Light microscopy (LM) of spores. a-c: Anthoceros bharadwajii Udar \& A.K. Asthana from Sierra Leone (BM001244143); d-f: A. bharadwajii from China (HSNU); g-i: A. caucasicus Steph. from Turkey (AYDN 2977). Distal faces (b, c, f, i) and proximal faces (a, d, e, g, h). Scale bar $10 \mu \mathrm{m}$.

Figure 4. SEM observations of spores. a-c: Anthoceros aff. bharadwajii Udar \& A.K. Asthana, from Sierra Leone collection (Figure 1), leg. A.J. Harrington 212 (BM001244143 p.p.). Lateral view (a), distal face (b) and (c) spore margin. d-f: Anthoceros bharadwajii from China, leg. Ying Yu 20100920-7 (HSNU). (d) Proximal, (e) distal face and (f) spore margin. g-i: Anthoceros caucasicus from Turkey, leg. M. Kirmaci \& H. Kürschner (AYDN 2977). (g) proximal, (h) distal face and (i). spore margin. Scale bar $10 \mu \mathrm{m} .(\mathrm{a}, \mathrm{b}, \mathrm{d}, \mathrm{e}, \mathrm{g}, \mathrm{h})$ and $5 \mu \mathrm{m}(\mathrm{c}, \mathrm{f}, \mathrm{i})$.

Figure 5. SEM micrographs of old spores. a-b: Anthoceros punctatus and c-d: Phaeoceros laevis. Proximal $(\mathrm{a}, \mathrm{c})$ and distal $(\mathrm{b}, \mathrm{d})$ faces. The two species are from the Sierra Leone sample (Figure 1), leg. A.J. Harrington 212 (BM001244143 p.p.). Scale bar $10 \mu \mathrm{m}$. 


\section{Acknowledgements}

We are grateful to Telmo Nunes for assistance with the SEM studies and to L. Ellis, curator of the BM herbarium, for kindly allowing us to study the plant material from Alan Harrington's collection. We thank Christine Cargill, who, with the editorial handling of the manuscript, greatly improved this note. We are grateful to the Curators of the bryophyte herbarium, Adnan Erdağ and Mesut Kirmaci of AYDN in Turkey, RuiLiang Zhu of HSNU in Shanghai and Sahut Chantanaorrapint of PSU Herbarium in Thailand for arranging the material on loan. David Draper was supported by the FCT Post-doctoral Fellowships Program (SFRH/BPD/100384/2014). 